\title{
Shelf-Life of Ready-To-Eat Retort Processed Pepper Chicken
}

\author{
P. Nalini ${ }^{1 *}$, Robinson J.J. Abraham², V. Appa Rao², R. Narendra Babu', \\ T. Nobal Rajkumar ${ }^{3}$, R. Rajkumar ${ }^{1}$ and R.S. Kathiravan ${ }^{1}$ \\ ${ }^{1}$ Mecheri Sheep Research Station, Pottaneri, Salem, Tamil Nadu, India \\ ${ }^{2}$ Department of Livestock Product Technology (Meat Science), Madras Veterinary College, \\ Chennai, Tamil Nadu, India \\ ${ }^{3}$ Veterinary Consultant, Aavin, Erode, Tamil Nadu, India \\ *Corresponding author
}

\section{A B S T R A C T}

\section{Keyw ords \\ Indigenous products, Chicken, Retort processing, $\mathrm{F}_{0}$ value, Storage study \\ Article Info \\ Accepted: \\ 07 February 2018 \\ Available Online: \\ 10 March 2018}

The study was undertaken to standardize a shelf-stable ready-to-eat pepper chicken using broiler meat by retort pouch processing. Three experiments were conducted, in the first experiment the recipe was standardized (pilot scale study) on the basis of sensory evaluation and in second experiment retort pouch processing temperature $\left(F_{0}\right.$ value) was determined based on references, commercial sterility test, visual observation, sensory evaluation and preliminary trials. The come up percentage was 27.27 and the $\mathrm{F}_{0}$ value was 7.2 minutes. In third experiment, shelf stability was assessed for a period of 90 days by microbiological, physico-chemical and sensory qualities by repeating the trials for six times. Results of the present study revealed that the pepper chicken from broiler meat was biochemically and microbially safe for the entire storage period.

\section{Introduction}

Ready-to-eat foods or products had been found to be microbiologically safe and organoleptically acceptable for a period ranging from three months to one year. The advent of modern urban dynamic lifestyle has created a demand for ready-to-eat food. The urban middle and upper middle class consumers have little time to do their cooking in a conventional manner and welcome ready to eat food products. Though such products are specially meant for consumption by the Armed Forces personnel during combat and special missions, they are also being consumed by participants of rowing, mountaineering expedition, motor rallies and during Antarctica expeditions. Moreover, urbanization has generated a considerable interest among civil population in such types of processed foods (Rajkumar et al., 2010).

Because of their strength, flexibility, and light weight, retort pouches have become a widely used alternative to traditional canning methods for preserving food and allowing it to stay fresh for many years. These pouches use less than 5\% of the packaging material of traditional rigid tin cans and help improve food quality, texture, flavor, and aroma. 
Thermal processing, i.e. heating, was one of the most important operations in food processing mostly used for pasteurization preservation, such as in canneries and pasteurization. In processing of food such as meats and vegetables, heat also acts to develop taste and flavor, and in addition to lower the microbial load in order to carry out physical changes to the food (Miri et al., 2008).

Thermally processed foods were in wide range and a variety of containers were used as packaging material. The processing techniques also differ from product to product and from package to package. Hence the retort designs and operating procedures also vary (Satish et al., 2005).

Advantages such as shelf-stability, less weight, less storage space, ease of opening and preparation and technical and commercial feasibility of using retortable pouches for the thermo-processed foods (Hu et al., 1995).

Traditional or ethnic dishes are important due to their delicacy and these products have great demand but are rarely commercialized due to their short shelf life and can be preserved either in the frozen or ready-to-eat forms (Bindu et al., 2010).

\section{Materials and Methods}

Deboned meat of broiler was bought from the local market and washed with portable water. Indigenously manufactured retort pouches (Pradeep Laminators, Pune) having four layer configurations (from inside 1. Cast polypropylene, 2. Biaxially oriented nylon, 3. Aluminium foil and 4. Polyethylene) were used for the study.

Formulation of recipe was standardized based on the information collected from the famous chef, preliminary study (pilot scale) and sensory evaluation.

\section{Preparation of pepper chicken gravy}

Pepper chicken gravy (Ingredients as per Table 1) was prepared separately by frying cinnamon, cloves, mace, lichens and poppy seeds in refined sunflower oil and then sliced onion was added and fried till it reached golden yellow colour. The sliced tomato was added and heated till all the water evaporated. Then freshly prepared ginger and garlic paste was added and sauted for 2 minutes, black pepper powder was added and sauted for 1 minute and then cashew nut paste and portable water was added and then cooked for 5 minutes. Finally cow's milk was added and mildly heated for 5 minutes. After processing all the pouches were wiped dry and kept in a dust proof cabinet at ambient temperature (25$30^{\circ} \mathrm{C}$ ).

\section{F0 value}

Retort processing temperature was determined based on the values obtained from the experiment conducted with laboratory model overpressure autoclave/retort. Laboratory model was supplied by M/s Lakshmi Engineering having a capacity of 25 pouches. Sealed pouches were subjected to thermal processing by maintaining the retort temperature at $121.1^{\circ} \mathrm{C}$. Pressure was maintained at 20 psi throughout the process by using steam-air mixture during heating and water-air mixture during cooling. The product core temperature and the lethal rates $\left(\mathrm{F}_{0}\right.$ value $)$ were noted and the $\mathrm{F}_{0}$ value was calculated by the following formula (Stumbo, 1973).

(PCT-121.1)

Lethal rates $/ \mathrm{F}_{0}$ value $(\mathrm{min})=\log 10^{-1}$

Where $\mathrm{PCT}=$ Product Core Temperature

Product core temperature was noted for every minute till the product was processed and the 
$\mathrm{F}_{0}$ value was calculated by adding all the lethal rates noted every minute.

\section{Storage studies}

\section{Commercial sterility test}

The commercial sterility study was done according to the Bureau of Indian Standards, 1971.

\section{Sensory evaluation}

Sensory evaluation was assessed by subjecting the samples to sensory scores of appearance, flavor, juiciness, tenderness and overall acceptability by a trained and semi-trained taste panel, by a 9-point hedonic scale.

\section{Microbial analysis}

Total viable count, anaerobic, coliform, staphylococcal, clostridial and yeast and mould counts of processed samples were determined by the method described by American Public Health Association, 1984 using media from Hi-Media, Mumbai.

\section{Physico-chemical parameters}

\section{pH, thio-barbituric acid number and tyrosine value}

$\mathrm{pH}$ was measured by using a digital $\mathrm{pH}$ meter (Cyberscan pH 510, Merck).

Thio-barbituric acid number (TBA) and tyrosine value (TV) was determined by the procedure outlined by Strange et al., (1977).

\section{Hunter colour}

Colour of the sample were tested using Hunter lab Mini scan XE plus Spectro-colorimeter (Model No. 45/O-L, Reston Virgenia, USA) with geometry of diffuse/80 (sphere $-8 \mathrm{~mm}$ view) and an illuminant of D65/10 deg (Bindu et al., 2007).

\section{Texture profile analysis}

Texture profile analysis was conducted using a Stable Microsystems Texturometer (Stable system Ltd., England, UK) model TA_HD plus texture analyser attached to software, texture expert and analyzed as per Bourne, 1978.

\section{Statistical analysis}

The data obtained were analyzed statistically in SPSS software (version 20.0) according to Snedocor and Cochran (1994).

\section{Results and Discussion}

The retort temperature and the product core temperature before processing were $35^{\circ} \mathrm{C}$ and $40^{\circ} \mathrm{C}$ respectively.

The product core temperature reached its first lethality rate of 0.001 , when the product core temperature was $86.9^{0} \mathrm{C}$ (Devadasan, 2004; Sreenath et al., 2017; Rajkumar et al., 2010).

To reach the first lethality, come up time (CUT) 17 minutes which was below the CUT value (Rajkumar et al., 2010) and the total lethality $\left(\mathrm{F}_{0}\right)$ received for pepper chicken was 7.2 (graph 1).

In commercial sterility test no tubes developed turbidity so the products were 'commercially sterile'.

Sensory scores (Table 2) decreased highly significantly in appearance, flavour, juiciness and tenderness and are in acceptable limits up to 90days of storage. The results are similar to the study made by Gopal et al., (2001), Shankar et al., (2002), Chandrasekar et al., (2004) and Bindu et al., (2007). 
Flow chart for retort processing of pepper chicken

Opening of pouch

$\downarrow$

Filling warmed chicken meat (100 gram) and gravy (150gravy)

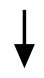

Removal of air from retort pouches (by injecting live steam)

Sealing of pouches using high pressure sealer

$\downarrow$

Keeping pouches in trays, racking and loading the pouches

$\downarrow$

Retorting at $121.1^{\circ} \mathrm{C}$

$\downarrow$

Cooling of pouches (product temperature $60^{\circ} \mathrm{C}$ )

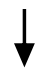

Unloading the pouches

Graph.1 Standardized Retort processing data (Fo value)

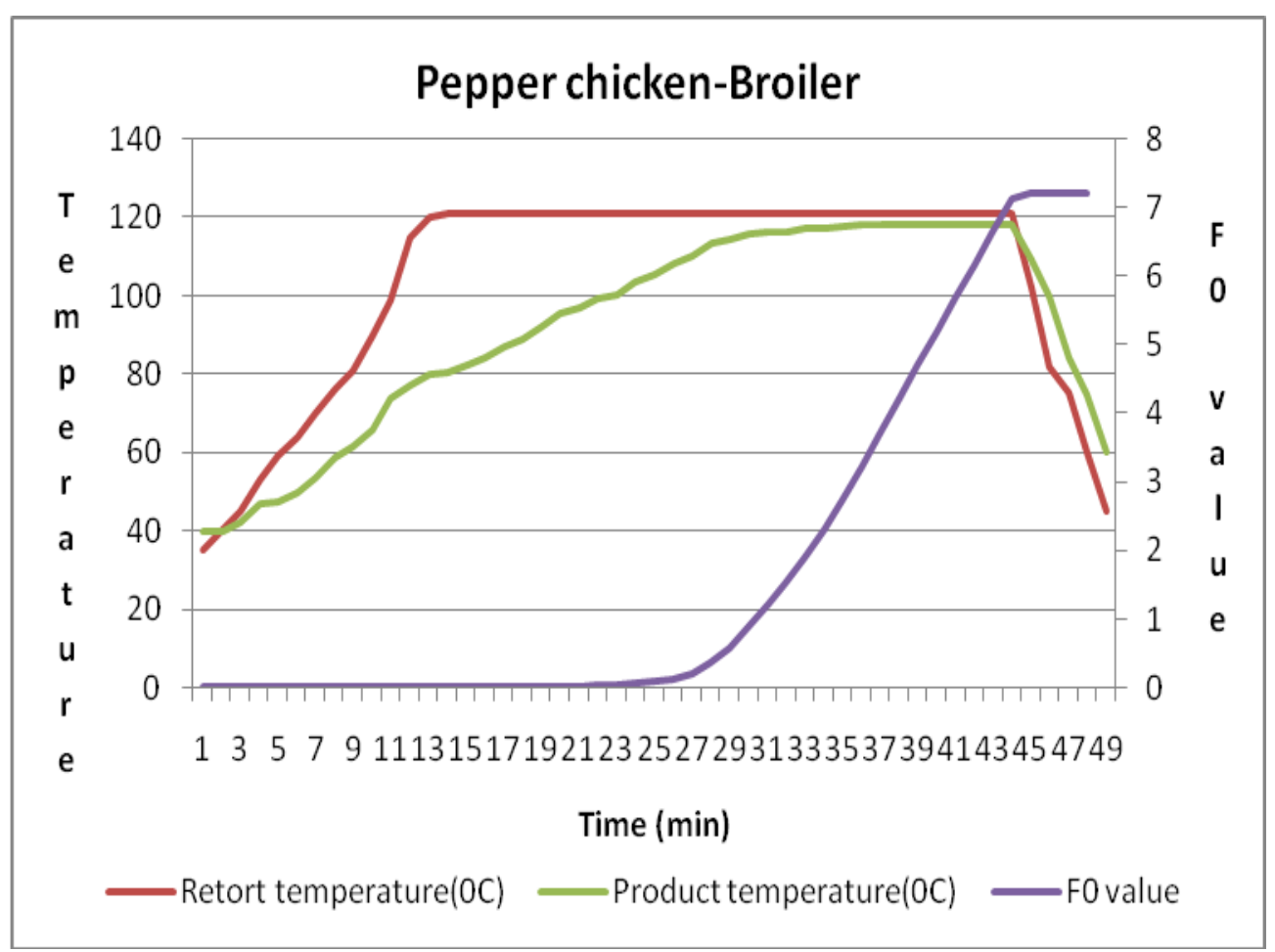


Table.1 Ingredient

\begin{tabular}{|c|l|c|c|}
\hline \multirow{2}{*}{ S. No. } & \multicolumn{2}{|c|}{ Ingredients } & \multicolumn{2}{c|}{ Percentage } \\
\hline 1. & Onion & 40.00 & 11.80 \\
\hline $\mathbf{2 .}$ & Tomato & 24.00 & 07.08 \\
\hline $\mathbf{3 .}$ & Ginger & 04.00 & 01.18 \\
\hline $\mathbf{4 .}$ & Garlic & 04.00 & 01.18 \\
\hline $\mathbf{5 .}$ & Curry leaves & 00.60 & 00.16 \\
\hline $\mathbf{6 .}$ & Coriander leaves & 00.60 & 00.16 \\
\hline $\mathbf{7 .}$ & Onion leaves & 00.60 & 00.16 \\
\hline $\mathbf{8 .}$ & Red chilli powder & 01.00 & 00.29 \\
\hline $\mathbf{9 .}$ & Coriander seed powder & 04.00 & 01.18 \\
\hline $\mathbf{1 0 .}$ & Black pepper powder & 05.00 & 01.47 \\
\hline $\mathbf{1 1 .}$ & Cinnamon & 00.20 & 00.06 \\
\hline $\mathbf{1 2 .}$ & Mace & 00.30 & 00.09 \\
\hline $\mathbf{1 3 .}$ & Poppy seeds & 00.20 & 00.06 \\
\hline $\mathbf{1 4}$ & Cloves & 00.30 & 00.09 \\
\hline
\end{tabular}

Table.2 Sensory evaluation score

\begin{tabular}{l} 
Sensory \\
score \\
\hline Appearance \\
\hline Flavour \\
\hline Juiciness \\
\hline Tenderness \\
\hline Over all \\
acceptability \\
\hline
\end{tabular}

\section{Storage period (in days)}

\begin{tabular}{|l|l|l|l|l|l|}
\multicolumn{1}{c|}{$\mathbf{0}$} & \multicolumn{1}{c|}{$\mathbf{1 5}$} & \multicolumn{1}{c}{$\mathbf{3 0}$} & \multicolumn{1}{c}{$\mathbf{6 0}$} & \multicolumn{1}{c|}{$\mathbf{9 0}$} & \multicolumn{1}{c}{ F value } \\
\hline $7.90^{\mathrm{b}} \pm 0.07$ & $7.87^{\mathrm{b}} \pm 0.10$ & $7.78^{\mathrm{ab}} \pm 0.10$ & $7.67^{\mathrm{ab}} \pm 0.09$ & $7.57^{\mathrm{a}} \pm 0.08$ & $2.49^{\mathrm{NS}}$ \\
\hline $7.78^{\mathrm{c}} \pm 0.08$ & $7.43^{\mathrm{a}} \pm 0.08$ & $7.70^{\mathrm{bc}} \pm 0.09$ & $7.60^{\mathrm{abc}} \pm 0.07$ & $7.50^{\mathrm{ab}} \pm 0.08$ & $3.17^{\mathrm{NS}}$ \\
\hline $7.83^{\mathrm{b}} \pm 0.13$ & $7.68^{\mathrm{ab}} \pm 0.11$ & $7.73^{\mathrm{ab}} \pm 0.13$ & $7.63^{\mathrm{ab}} \pm 0.11$ & $7.43^{\mathrm{a}} \pm 0.11$ & $1.57^{\mathrm{NS}}$ \\
\hline $7.71 \pm 0.08$ & $7.42 \pm 0.29$ & $7.62 \pm 0.09$ & $7.60 \pm 0.09$ & $7.52 \pm 0.06$ & $0.63^{\mathrm{NS}}$ \\
\hline $7.97^{\mathrm{b}} \pm 0.04$ & $7.82^{\mathrm{ab}} \pm 0.09$ & $7.93^{\mathrm{b}} \pm 0.04$ & $7.68^{\mathrm{a}} \pm 0.08$ & $7.82^{\mathrm{ab}} \pm 0.05$ & $2.99^{* *}$ \\
\hline
\end{tabular}

Table.3 Microbial count of pepper chicken

\begin{tabular}{|c|c|c|c|c|c|c|}
\hline \multirow[t]{2}{*}{ Microbial count } & \multicolumn{6}{|c|}{ Storage period (in days) } \\
\hline & $\mathbf{0}$ & 15 & 30 & 60 & 90 & F value \\
\hline Total viable count & $0.45^{\mathrm{a}} \pm 0.02$ & $0.51^{\mathrm{a}} \pm 0.02$ & $0.50^{\mathrm{a}} \pm 0.01$ & $0.48^{\mathrm{b}} \pm 0.02$ & $0.47^{\mathrm{c}} \pm 0.02$ & $24.09^{* *}$ \\
\hline Anaerobic count & ND & ND & ND & ND & ND & - \\
\hline $\begin{array}{c}\text { Staphylococcal } \\
\text { count }\end{array}$ & ND & ND & ND & ND & ND & - \\
\hline Coliform count & ND & ND & ND & ND & ND & - \\
\hline $\begin{array}{c}\text { Yeast and mould } \\
\text { count } \\
\end{array}$ & ND & ND & ND & ND & ND & - \\
\hline Clostridium count & ND & ND & ND & ND & ND & - \\
\hline Salmonella count & ND & ND & ND & ND & ND & - \\
\hline
\end{tabular}


Table.4 Physico-chemical characteristics

\begin{tabular}{c|c|c|c|}
$\begin{array}{c}\text { Storage period } \\
\text { (in days) }\end{array}$ & $\mathrm{pH}$ & TBA & TV \\
\hline 0 & $5.40^{\mathrm{c}} \pm 0.02$ & $0.45^{\mathrm{a}} \pm 0.00$ & $6.04^{\mathrm{a}} \pm 0.03$ \\
\hline 15 & $5.38^{\mathrm{bc}} \pm 0.02$ & $0.51^{\mathrm{a}} \pm 0.00$ & $6.26^{\mathrm{b}} \pm 0.06$ \\
\hline 30 & $5.36^{\mathrm{abc}} \pm 0.01$ & $0.50^{\mathrm{c}} \pm 0.00$ & $6.38^{\mathrm{c}} \pm 0.06$ \\
\hline 60 & $5.33^{\mathrm{ab}} \pm 0.02$ & $0.48^{\mathrm{b}} \pm 0.00$ & $6.73^{\mathrm{d}} \pm 0.08$ \\
\hline 90 & $5.31^{\mathrm{a}} \pm 0.01$ & $0.47^{\mathrm{b}} \pm 0.00$ & $6.93^{\mathrm{e}} \pm 0.05$ \\
\hline F value & $5.45^{* *}$ & $52.80^{* *}$ & $222.62^{* *}$ \\
\hline
\end{tabular}

Table.5 Hunter colour scores

\begin{tabular}{|l|}
\multicolumn{1}{c|}{$\begin{array}{c}\text { Hunter colour } \\
\text { scores }\end{array}$} \\
\hline Lightness $(\mathbf{L})$ \\
\hline Redness $\left(\mathbf{a}^{*}\right)$ \\
\hline Yellowness $\left(\mathbf{b}^{*}\right)$ \\
\hline Hue \\
\hline Chroma \\
\hline
\end{tabular}

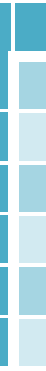

\section{Storage period (in days)}

\begin{tabular}{|c|c|c|}
\hline $\mathbf{0}$ & $\mathbf{9 0}$ & F value \\
\hline $48.83 \pm 0.23$ & $48.86 \pm 0.35$ & $0.00^{\mathrm{NS}}$ \\
\hline $13.60 \pm 0.52$ & $11.82 \pm 0.17$ & $10.41^{* *}$ \\
\hline $34.10 \pm 0.27$ & $31.55 \pm 0.25$ & $47.44^{* *}$ \\
\hline $68.28 \pm 0.74$ & $69.47 \pm 0.41$ & $1.97^{\mathrm{NS}}$ \\
\hline $36.73 \pm 0.09$ & $33.70 \pm 0.30$ & $58.83^{* *}$ \\
\hline
\end{tabular}

Table.6 Effect of storage on texture profile

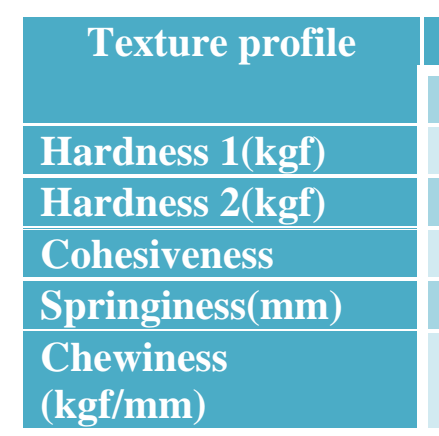

\begin{tabular}{|c|c|c|}
\hline \multicolumn{3}{|c|}{ Storage period (in days) } \\
\hline $\mathbf{0}$ & $\mathbf{9 0}$ & F value \\
\hline $16.05 \pm 0.14$ & $59.21 \pm 0.58$ & $5.29^{* *}$ \\
\hline $15.08 \pm 0.073$ & $52.50 \pm 0.51$ & $5.30^{* *}$ \\
\hline $0.35 \pm 0.01$ & $0.43 \pm 0.01$ & $24.76^{* *}$ \\
\hline $0.34 \pm 0.01$ & $0.43 \pm 0.00$ & $109.33^{* *}$ \\
\hline $9.51 \pm 0.05$ & $1.59 \pm 0.05$ & $12.94^{* *}$ \\
\hline
\end{tabular}

$\mathrm{n}=6$ observations

$* *$ - highly significant $(\mathrm{P}<0.01)$ difference

* - significant $(\mathrm{P}<0.05)$ difference

NS - No significant $(\mathrm{P} \geq 0.05)$ difference

ND - Not Detected

Microbial study (Table 3) reveals, anaerobic, staphylococcal, coliform, Clostridium, Salmonella and yeast and mould were absent on ' 0 ' day and the total viable count was $0.45 \pm 0.02$ which increased significantly on $90^{\text {th }}$ day to $0.47 \pm 0.02 \log$ cfu. Total viable count at $35^{\circ} \mathrm{C}$ should be less than $10^{7}$ per gram and that Salmonella should be detected in not less than one of five, $25 \mathrm{~g}$ samples of meat (ICMSF, 1974). Bacterial numbers of $3.0 \log _{10}$ colony forming units $(\mathrm{cfu}) / \mathrm{cm}^{2}$ may be regarded as indication of good hygiene or of an efficient commercial operation (Shankar et al., 2002). So the products are microbially safe for consumption up to 90days of storage. 
Physico chemical parameters (pH, TBA, TV) are presented in Table 4. The $\mathrm{pH}$ was $5.40 \pm 0.02$, indicating that it is towards the acidic side. The acidic nature of the product can be attributed by the curry ingredients like tomato. During storage, the $\mathrm{pH}$ of the products was found to exhibit a decreasing trend and it was $5.31 \pm 0.01$ on $90^{\text {th }}$ day which are significantly lower as compared to initial values (Sreenath et al., 2007).

The TBA value on ' 0 ' day was $0.45 \pm 0.00$ and on $90^{\text {th }}$ day TBA number decreased to $0.47 \pm 0.00$ which agrees with retort processed shrimp and squid masala (Sreenath et al., 2007; Park et al., 1993; Aubourg et al., 1995).

The tyrosine values on ' 0 ' day was $6.04 \pm 0.03$ and on $90^{\text {th }}$ day of storage the tyrosine values increased significantly to $6.93 \pm 0.05$. This in accordance with retort processed Chettinad chicken from spent hen and broiler meat and assessment of storage stability at room temperature (Rajan, 2009).

Hunter colour scores are presented in Table 5. Pepper chicken made from broiler meat had an initial $\mathrm{L}$ value of $48.83 \pm 0.23$ which reduced significantly to $48.86 \pm 0.35$ on $90^{\text {th }}$ day. Redness $a^{*}$ of the product was found to decrease slightly with storage and was $11.82 \pm 0.17$ at the end of storage study. The yellowness $b^{*}$ value on ' 0 ' day was $34.10 \pm 0.27$ which on storage changed significantly. Hue value on ' 0 ' day was 69.47 \pm 0.41 . Hue value did not change significantly during storage. Chroma (colour intensity) value on ' 0 ' day was $36.73 \pm 0.09$. At the end of $90^{\text {th }}$ day chroma $33.70 \pm 0.30$ which decreased highly significantly, this is in accordance with the in retort processed Chettinad style goat meat (Rajkumar et al., 2010).

Texture is one of the important quality attribute affecting the consumer acceptability of a food product. The analysis of texture (Table 6) becomes even more important in case of canned products which are intended for long periods of storage as storage period is one of the determinants in texture (Ahmed et al., 1972) Hardness 1 and 2 for on ' 0 ' day were $16.05 \pm 0.14$ and $15.08 \pm 0.073 \mathrm{kgf}$, respectively and on $90^{\text {th }}$ day the hardness 1 and 2 values increased $59.21 \pm 0.58$ and $52.50 \pm 0.51073 \mathrm{kgf}$, respectively. The results are similar to the retort processed Chettinad chicken meat and retort processed Chettinad style goat meat (Rajkumar et al., 2010; Selvin, 2010). Hardness is mainly due to retort processing which causes conversion of collagen to gelatin and dissociation of muscle protein of goat meat. The springiness values on 0 and $90^{\text {th }}$ day was $0.39 \pm 0.02$ and $0.45 \pm 0.00$ which changed significantly during storage at room temperature. The cohesiveness and chewiness on ' 0 ' day was $0.37 \pm 0.02$ and $3.01 \pm 0.42$ and on $90^{\text {th }}$ day of storage was $0.45 \pm 0.01$ and $6.52 \pm 0.98$ respectively which increased highly significantly during the storage period.

Retort processed pepper chicken can be safely stored up to 90 days at room temperature without changes in its nutritive and sensory quality. The cost of production was in the affordable range of Rs.50 per pouch $(250 \mathrm{~g})$. Hence it is felt that the retort processing technique can be useful in popularizing traditional products like pepper chicken and making it available to different places of the country as well as all over the world as heritage south Indian products of Indian origin.

\section{References}

Ahmed, E. M., J. A. Koburger and Mendenhall, V. T. 1972. Factors affecting texture on a cocktail shrimp. Journal of Textural Studies. 3: 186-193. 
APHA (American Public Health Association). 1984. Compendium of Methods for the Microbiological Examination of Foods. M. L. Speck. American Public Health Association, Washington, DC. $2^{\text {nd }}$ Edn. (Ed).

Aubourg, S., I. Medina and Perez-Martin R. A. 1995. Comparison between conventional and fluorescence detection methods of cooking-induced damage to tuna fish lipids. Journal of Science of Food and Agriculture. 200: 25-255.

Bindu, J., C. N. Ravishankar and Srinivasa Gopal, T. K. 2007. Shelf life evaluation of a ready-to-eat black cam (Villorita cyprinoides) product in indigenous retort pouches. Journal of Food Engineering. 78: 995-1000.

Bindu, J., C. N. Ravishankar, T. K. Srinivasa Gopal and Mallick, A. K. 2010. Investigation of shelf life and heat penetration attributes of ready to eat "Fish peera" from Anchovy (Stolephorous commersoni) in retort pouches. Journal of Food Processing and Preservation. 34: 207-222.

Bourne, M. C. 1978. Texture profile analysis. Food Technology. 32: 62-66.

Chandrasekar, V., T. K. S. Gopal, and Rai, R. D. 2004. Heat penetration characteristics and shelf-life studies of mushrooms in brine processed in retort pouches. Packaging Technology and Science. 17: 213-217.

Devadason, P. 2004. Thermal processing of shelf stable buffalo meat blocks in retort pouches. Ph.D. Thesis submitted to Indian Veterinary Research Institute. Deemed University, Bareilly, India.

Gopal, T. K., P. K. Vijayan, K. K. Balachandran, P. Madhavan and Lyer, T. S. G. 2001. Traditional Kerala style fish curry in indigenous retort pouch. Food control. 1: 523-527.

$\mathrm{Hu}$, K. H., A. Nelson, R. R. Legault and Steinberg, M. P. 1995. Feasibility of using plastic film packages for heat processed foods. Food technol. 19: 236 $-240$.

ICMSF (International Commission on Microbiological Specifications for Foods), 1974.

IS: 2168- 1971. Specification for Pomfret canned in Oil. Indian Standard Institute, Manak Bhavan, 9 Bahadur Saha Zafar Marg, New Delhi-1.

Miri, T., A. Tsoukalas, S. Bakalis, E. N. Pistikopoulos, B. Rustem and Fryer, P. J. 2008. Global optimization of process conditions in batch thermal sterilization of food. Journal of Food Engineering. 87: 485-494.

Narayan Prasad, N., M. Siddalingaswamy, P. M. Parameswariah, K. Radhakrishna, R. V. Rao, K. R. Viswanathan and Santhanam, K. 1999. Proximate and mineral composition of some processed traditional and popular Indian dishes. Food Chemistry. 68: 87-94.

Park, J., K. S. Rhee, B. K. Kim and Rhee, K. C. (1993). High-protein texturized products of defatted soy flour, corn starch and beef: shelf-life, physical and sensory properties. Journal of Food Science. 58:21-27.

Rajan, S. 2009. Studies on preparation of chettinad chicken, its retort processing and assessment of storage stability at room temperature. M.V.Sc. Thesis submitted to Tamil Nadu Veterinary and Animal Sciences University, Chennai - 51 .

Rajkumar, V., K. Dushyanthan and Das, A. K. 2010. Retort pouch processing of Chettinad style goat meat curry-a heritage meat product. Journal of Food Science and Technology. 47: 372-379.

Satish, H. S. 2005. Retort systems and Operations. In: Lecture document of short term training progrmme on thermal processing of food: Principles, practices and packaging aspects, May 
16-20. CFTRI, Mysore, India. pp: 2132.

Selvin, M. S. 2010. Technology development for indigenous processed meat productChettinad chicken, B.Tech in Food processing and Engineering thesis submitted to Karunya University, Coimbatore, India.

Shankar, C. N. R., T. K. S. Gopal and Vijayan, P. K. 2002. Studies on heat processing and storage of seer fish curry in retort pouches. Packaging Technology and Science. 15: 3-7.

Sheridan, J. J. and Lynch, B. 1979. Effect of microbial contamination on the storage of beef carcasses in a meat factory. International Journal of Food Science and Technology. 3: 43-52.
Snedocor, G. W. and Cochran, W. G. 1994. Statistical methods. The Iowa state university press, Iowa.

Sreenath, G. P., M. X. K. Anthony, R. C. Nagarajarao, J. Bindu and Gopal, S. T. K. 2007. Standardization of process parameters for ready-to-eat squid masala in indigenous polymer-coated tin-free steel cans. International Journal of Food Science and Technology. 42: 1148-1155.

Strange, E. D., R. C. Benedict, J. C. Smith and Swift, C. E. 1977. Evaluation of rapid tests for monitoring alterations in meat during storage. I. Intact meat. Journal of Food Protection. 40: 843.

Stumbo, C. R. 1973. In: Thermo Bacteriology in Food Processing ( $2^{\text {nd }}$ ed.). Academic Press, New York. pp. 93-120.

\section{How to cite this article:}

Nalini, P., Robinson J.J. Abraham, V. Appa Rao, R. Narendra Babu, T. Nobal Rajkumar, R. Rajkumar and Kathiravan, R.S. 2018. Shelf-Life of Ready-To-Eat Retort Processed Pepper Chicken. Int.J.Curr.Microbiol.App.Sci. 7(03): 832-840. doi: https://doi.org/10.20546/ijcmas.2018.703.097 